NBER WORKING PAPER SERIES

\title{
CONTROLLING THE PRICE LEVEL
}

\author{
Robert E. Hall
}

Working Paper 6914

http://www.nber.org/papers/w6914

\section{NATIONAL BUREAU OF ECONOMIC RESEARCH 1050 Massachusetts Avenue \\ Cambridge, MA 02138 \\ January 1999}

Paper prepared for the Irving Fisher Conference at Yale University, May 1998. This research was supported by the National Science Foundation under grant SOC SBR-9730341 and is part of the research program on Economic Fluctuations and Growth of the NBER. I am grateful to Robert Shiller and Christopher Sims for helpful comments. The views expressed here are those of the author and do not reflect those of the National Bureau of Economic Research.

( 1999 by Robert E. Hall. All rights reserved. Short sections of text, not to exceed two paragraphs, may be quoted without explicit permission provided that full credit, including ${ }^{\circledR}$ notice, is given to the source. 
Controlling the Price Level

Robert E. Hall

NBER Working Paper No. 6914

January 1999

JEL No. E42

ABSTRACT

Governments determine the size of the unit of value just as they determine the length of the length and weight of physical units of measure. What are the different ways that a government can control the size of the unit of value, that is, control the price level? In general, the government designates a resource-gold, paper currency, another country's currency-and defines its unit of value as a particular amount of that resource. An interesting variant-proposed by Irving Fisher in 1913 and implemented more recently in Chile - is to alter the resource content of the unit to stabilize the price level. Another idea is to alter the interest rate paid on reserves in a way that stabilizes the price level.

Robert E. Hall

Hoover Institution

Stanford University

Stanford, CA 94305

and NBER

hall@hoover.stanford.edu 


\section{Introduction}

Modern economists generally think about the price level within the framework of the monetary institutions of the United States and other advanced economies. The central bank controls the quantity of money. The price level-in the longer run-equates the demand for money to the supply. But what about economies without central banks? What determines their price levels? Can an economy use different principles to control its price level, beside the tried and true central bank paradigm?

In modern economies, the government is responsible for determining standards for weight, volume, distance, and value. It is helpful to think about the determination of the price level as an exercise of the government's standardsetting power. The government establishes the national unit of length by a reference unit. In the United States for many years, a metal bar stored in Washington determined the length of the yard (now the reference unit is a multiple of the wavelength of cesium). The government can set a national standard for the length of the yard without producing and selling yardsticks itself. The ultimate function of the government in this and other standards is rooted in contract law: When a contract calls for the delivery of a specified number of yards of wire, the legal standard to determine if the seller has complied with the contract is whether the length of wire is the agreed amount in terms of the government's reference standard.

The determination of the unit of value operates in precisely the same way. Article I of the U.S. Constitution grants Congress the power to determine the monetary unit in the same sentence as it grants the power to determine units of weight and measure. The government develops a monetary unit as an abstraction. 
Just as the yard is a certain number of wavelengths of cesium, the dollar-as originally defined by Congress-was .04838 of an ounce of gold. We teach today-in the context of modern monetary institutions - that the dollar is both a unit of value and a store of value. But the functions can be separated. The government need not produce dollars in order to define the dollar, any more than it has to produce yardsticks in order to define the yard.

Once the government has established a monetary unit, the rest of the economy typically adopts the unit for many different purposes. One central application is that merchants place prices on goods stated in terms of the monetary unit. A second is that accounts are kept in the unit. And a third is that the unit denominates securities that are used to carry out transactions and to store wealth. In all modern economies, the government provides some of those securities itself. In particular, governments monopolize the supply of currency denominated in the national monetary unit. Because all modern governments issue currency denominated in their own monetary units, monetary economics has blurred the distinction between the monetary unit as an abstract unit like the yard, and the store of value, analogous to the yardstick.

History provides one way to see the distinction. The U.S. government did not issue any currency until the Civil War. For the first 70 years of the country's history, the government defined the dollar and controlled the price level without supplying currency or any other security that had a role in transactions. There is considerable confusion in many accounts of how the government controlled the price level in that regime. The confusion arises from trying to answer the question within the framework of modern institutions where control of the quantity of money is central to controlling the price level. 


\section{A General Framework}

To define the unit of value, the government makes a definition of the following generic form:

The unit of value is $x_{t}$ units of resource $y$.

Here are some examples:

\begin{tabular}{|c|c|c|c|}
\hline Provenance & $\begin{array}{l}\text { Name of unit of } \\
\text { value }\end{array}$ & Resource & $\begin{array}{l}\text { Rule for number of units of } \\
\text { resource }\end{array}$ \\
\hline $\begin{array}{l}\text { U.S. before the } \\
\text { Civil War }\end{array}$ & Dollar & Gold & $.04838 \mathrm{oz}$ \\
\hline Modern U.S. & Dollar & $\begin{array}{l}\text { Paper dollar: } \\
\text { bearer security } \\
\text { issued by the } \\
\text { Federal Reserve }\end{array}$ & 1 \\
\hline $\begin{array}{l}\text { Proposal by Irving } \\
\text { Fisher [1913] }\end{array}$ & Dollar & Gold & $\begin{array}{l}\text { Amount needed to buy } \\
\text { the cost of living bundle }\end{array}$ \\
\hline Modern Chile & $\begin{array}{l}\text { Unidad de } \\
\text { Fomento }\end{array}$ & $\begin{array}{l}\text { Paper Peso: } \\
\text { bearer security } \\
\text { issued by Bank of } \\
\text { Chile }\end{array}$ & $\begin{array}{l}\text { Number required to buy } \\
\text { the cost of living bundle }\end{array}$ \\
\hline Argentina, Burma & Peso, FEC & U.S. dollar & 1 \\
\hline
\end{tabular}

Let $r_{t}$ be the value of one unit of the resource relative to the cost of living bundle. Then the purchasing power of the unit of value is

$$
v_{t}=x_{t} r_{t}
$$


and the price level is

$$
p_{t}=\frac{1}{v_{t}}=\frac{1}{x_{t} r_{t}}
$$

Note that these relationships are purely definitional. They do not tell us whether a change in the resource content of the monetary unit, $x_{t}$, changes the purchasing power of the resource, $r_{t}$, or the purchasing power of the monetary unit, $v_{t}$. They also do not describe how an intervention in the resource market affects either $r_{t}$ or other variables in the economy. In particular, nothing in these definitional equations takes a stand on issues of monetary non-neutrality.

Monetary policies for controlling the price level fall into three categories:

1. Passive policies that let a market determine $r_{t}$ without government intervention and keeps $x_{t}$ at a constant level. The gold standard is a leading example. the government sets the gold content of the monetary unit once and for all, and does not intervene in the gold market. Argentina's policy as of 1998 of defining its monetary unit as one U.S. dollar is another example.

2. Active policies that let a market determine $r_{t}$ without government intervention and alter $x_{t}$ in order to keep the price level close to constant. An example is the compensated dollar advocated by Irving Fisher [1913].

3. Active policies that keep $x_{t}$ at one and intervene in the market for the resource so as to stabilize its purchasing power $r_{t}$. Most modern governments use this type of policy, where the resource is a security issued by the government (currency and reserves) and the intervention alters the supply of the security. 


\section{Passive Policies for Controlling the Price Level}

The gold standard as practiced by the United States before the Civil War is a good example of a completely passive policy. The government did not issue any transactional securities other than a small volume of gold coins that had full gold value. The government did not intervene in the gold market. Private securities, including bank notes, were denominated in dollars, which meant that each dollar obligation was, ultimately, an obligation to deliver .04838 of an ounce of gold. ${ }^{1}$

What controls the price level under the gold standard? A common answer is the specie flow mechanism. Should the U.S. price level rise above its equilibrium level, the reasoning goes, the purchasing power of gold would be lower in here than in, say, Britain. Gold would flow to Britain. With less gold in the United States, banks would issue less money and the price level would fall back to equilibrium. Under a gold standard, would the price level be indeterminate in a completely closed economy, where specie could not flow? The answer is "no"- the question reveals that the specie flow theory is incomplete.

Specie flow is just one of many mechanisms involved in the determination of the equilibrium purchasing power of gold. In addition, with low purchasing power of gold, more gold would be used for jewelry and less would be mined in the first place. Standard principles of economics apply to the complicated question of the equilibrium value of gold in terms of other goods and services.

One additional complication deserves mention. The involvement of gold in the monetary system is itself a determinant of the demand for gold and thus of its purchasing power. The demand for gold arising from its monetary role can

\footnotetext{
1 The definition of the dollar was actually a little more complicated, because it involved the alternative of silver as well. But little is lost by my simplification.
} 
change over time - in particular, it may rise during financial panics, when the public seeks to exchange its financial instruments denominated in gold for gold itself. Hence it would not be appropriate to look at the behavior of the purchasing power of gold during a period when the gold standard was not in effect as a guide to the likely behavior of the purchasing power of gold (and thus the price level) under the hypothetical alternative of a gold standard.

\section{Policies for Controlling the Price Level Based on Varying the Resource Content of the Monetary Unit}

Irving Fisher [1913] developed a detailed proposal for price stability based on systematic variation in the gold content of the dollar. His basic idea was to define the dollar as enough gold to buy the cost of living bundle. If this definition could be in effect from day to day, the purchasing power of the dollar would be exactly constant. Fisher thought carefully about how to apply this idea to achieve a stable dollar in practice. ${ }^{2}$

To stabilize the price level at a level $p_{0}$, the rule, in terms of the notation introduced above, is

$$
x_{t}=\frac{1}{p_{0} r_{t}}
$$

Fisher drew up detailed rules setting forth the mechanics of stabilized money based on this rule. The steps are, first, measure the cost of living according to the

\footnotetext{
2 At all times, the discussion of Fisher's idea has been confused by being embedded in a framework where the quantity of money was an important variable, in part because Fisher's own thinking prior to making the proposal emphasized the quantity of money. See Patinkin [1993] for a thorough discussion.
} 
prices quoted by merchants under the most recent definition of the monetary unit. Second, adjust the resource content of the monetary unit, $x_{t}$, by the same proportion that the measured price level misses the target, $p_{0}$. Fisher presumed the use of gold as the resource, so his rule was to adjust the gold content of the dollar as needed to keep the purchasing power of the dollar constant. Fisher pioneered measurement techniques for the cost of living in order to make this idea practical.

To my knowledge, Fisher's idea has never been used with a precious metal as the resource underlying the monetary unit. Most probably the neglect has been to society's benefit. Fluctuations in the purchasing power of gold have been sufficiently large that substantial changes in the gold content of the monetary unit would have been needed to stabilize prices. Moreover, the nature of the forces that change the dollar price of gold may be such that anticipatory, discretionary monetary policy would be less disruptive to economic activity than the mechanical application of Fisher's scheme.

Any credible method for price stabilization, including Fisher's, will prevent monetary panics precipitated by fears of coming inflation, when the prices of gold and other commodities rise sharply. Consequently, the wide swings in the purchasing power of gold seen during periods, such as 1980, when the credibility of price stability was in doubt, cannot be used to measure the magnitude of the changes in the purchasing power of gold that Fisher's formula would be called upon to offset. Nonetheless, it appears that other sources of volatility in the purchasing power of gold would stand in the way of Fisher's scheme based on gold as the resource. One such source is financial panics, where the public loses faith in banks and seeks to hold more wealth in gold and other commodities. In the face of a panic, the necessary decline in the gold content of the monetary unit could be achieved under Fisher's scheme only by waiting for actual deflation to trigger the appropriate adjustment. Portfolio shifts originating in other countries 
also put stress on Fisher's formula - for example, the revolution in Iran coincided with a large increase in the purchasing power of gold that would have required months or years of grinding application of the formula before it found the right decrease in the gold content of the dollar.

In place of Fisher's mechanical formula, it appears in retrospect that it would be better to define the gold content of the dollar, $x_{t}$, as an instrument of discretionary monetary policy. Alan Greenspan could probably considerably outperform Fisher's formula, because he could use all available information about the current and likely future purchasing power of gold and adjust the gold content of the dollar before deflation or inflation actually occurred.

Fisher was aware of the practical problems that would attend variations in the gold content of the dollar. Anticipated and significant changes of the content would induce large movements between demand instruments denominated in dollars and the gold which these instruments entitle the holder to obtain on demand. He proposed a fee on these transactions to limit their magnitude. The administration of the compensated dollar is similar to the operation of a crawling peg in foreign exchange markets. Chile has successfully overcome the same problems in more than 30 years of operation of the Unidad de Fomento, to be discussed shortly.

Fisher's discussion of the compensated dollar is marred by his dedication to monetary institutions as they existed in the United States at the time he wrote. During the Civil War, the federal government imposed a monopoly on currency which it has retained to the present. Fisher presumed the continuation of the monopoly, so that his discussion deals simultaneously with the definitional role of the government—setting the gold content of the dollar, $x_{t}$, at each moment—and with the role of the government as the sole issuer of currency denominated in that unit. His discussion deals extensively with the question of the credibility of the 
government's promise to redeem gold certificates with the designated weight of gold. This is a problem of government finance that is logically separate from the definition of the monetary unit. Had Fisher placed his discussion in the context of the monetary institutions existing before the Civil War, his explanation of the idea would have been vastly simpler. In those institutions, private organizations would issue securities, including currency, denominated in the dollar. The market value of the instruments would reflect public knowledge of the creditworthiness of the issuers, just as for all private securities at all times. The successful issuers of currency would be the organizations with reputations strong enough to maintain the market values of their securities at exact par. These topics are no different under a monetary unit defined as a time-varying amount of a resource than under a unit defined as a fixed amount of the resource.

The better application of Fisher's program for defining a self-stabilizing monetary unit is to use a resource with more stable purchasing power. The best idea in theory would be to define the unit of value directly in terms of the cost of living bundle, but this approach is completely impractical. The resource underlying the definition must be one in which actual transactions can occur. In practice, this principle limits the resource to standardized metals and other commodities, or to securities. Earlier research of mine in Fisher's framework demonstrated to my satisfaction that no bundle of commodities would work (Hall [1982]). This leaves securities. Actual experience, not just armchair research, has demonstrated beyond doubt that defining the monetary unit as $x_{t}$ units of a standardized security is a foolproof way to create a self-stabilized monetary unit.

Though Fisher was regarded during his lifetime and long after as a crackpot visionary, his idea for self-stabilized money has been a complete success in actual practice. Since 1967, Chile has had a monetary unit, the Unidad de Fomento, operated according to Fisher's principles. The resource underlying the 
UF is a bearer security of the Bank of Chile. The number $x_{t}$ is published every day in every newspaper. An elaborate but successful formula changes the peso content of the UF each day so as to track the best estimate of that day's cost of living; the formula is driven by monthly data from the cost of living index. Soon after the introduction of the UF, essentially all forward contracts in Chile came to be written in UFs - the country achieved universal cost of living indexation painlessly. Every apartment lease, mortgage, savings account, and pension is stated in UFs. The idea is also in practice in Colombia, Ecuador, Mexico, and Uruguay, but its use is less widespread in those countries.

Interestingly, the success of the UF has remained unknown, or at least unremarked upon, among economists in every country of the world outside Latin America. A notable exception is the recent work of Robert Shiller [1998a and b].

As I noted earlier, fluctuations in the purchasing power of the resource underlying the definition of the monetary unit are an inconvenience in Fisher's scheme. Could we design a security whose purchasing power is constant? If we could, it would be unnecessary to distinguish between the security and the monetary unit. Chile would not need to have a peso and a UF if the terms of the peso could be altered so that its purchasing power was constant. It turns out to be straightforward to create such a security. I will discuss it in the second part of the next section. Shiller [1998a] discusses an interesting alternative, where a secondary monetary unit along the lines of the UF becomes the standard way to quote prices and denominate securities and the primary monetary unit lurks in the background to provide a reference level of value. 


\section{Policies for Controlling the Price Level Based on Intervening in the Resource Market}

Intervention in a resource market can take the form of altering the supply of the resource or the return that it pays. The first is the basis of price-level control in all modern economies and the second is an alternative with certain potential advantages.

\section{A. Controlling the supply of the resource}

When the resource is a physical substance, such as gold, the government can influence its purchasing power by altering the supply of the resource in the hands of the public. The government raises the purchasing power of gold (and lowers the price level under a passive gold standard) by purchasing gold and retiring it to an inactive stockpile. If a stockpile has been built up in the past, the government lowers the purchasing power of gold and raises the price level by selling from the stockpile.

Stabilizing the price level by buying and selling gold or another physical resource that defines the monetary unit has all the problems of any commodity price stabilization scheme. In order to guard against deflation, the government must hold an expensive stockpile of the resource. At all times, there will be political pressure from producers to purchase more of the resource and opposition to sales when the policy rule calls for sales. Further, because gold and other resources typically trade in world markets, the government must act on a scale large enough to influence the world purchasing power of the resource. Among the governments that define their monetary units in a particular resource, no more than one can stabilize the purchasing power of its monetary unit by intervening in the resource market.

The use of a financial security as the resource-and stabilization of the price level through variations in the quantity supplied-forms the basis of the 
monetary systems of all large modern economies. The security is non-interestbearing reserves together with currency. Because the government invariably stands ready to exchange currency notes of different denominations and reserves at fixed ratios, the various securities form a Hicksian composite good. I will refer to the composite as reserves, but currency is actually the larger component by far.

The purchasing power of a unit of reserves is determined by the standard considerations of traditional monetary economics. There is a demand for reserves arising from their usefulness in carrying out transactions. The demand is greater if there are reserve requirements, but demand is positive even without reserve requirements. ${ }^{3}$ The issue can be framed as: In an economy with a given number of pieces of paper with $\$ 1$ written on them, useful for carrying out transactions, what will be the value of those pieces of paper relative to goods and services in general? The analysis determines the level of the variable $r_{t}$ in the notation introduced earlier. Since the resource content of the monetary unit, $x_{t}$, is held at one in every country except those using the UF, the price level is simply the reciprocal of the purchasing power of a unit of reserves: $p_{t}=\frac{1}{r_{t}}$.

Notice that the analysis is exclusively real. It balances the physical volume of currency and reserves against other goods and services and finds the relative price that achieves equilibrium. Building a detailed model of the demand for reserves involves the contentious issues of standard monetary economics: Does money belong in the utility function? In the production function? Whatever the resolution of these issues, it remains the case that there will be an equilibrium relative price between reserves and other goods and services. 
Control over the price level is achieved, in this type of system, by adjustment of the supply of reserves. The demand for reserves fluctuates predictably and unpredictably over time. Stability of prices requires that supply be adjusted to match every movement of demand. Moreover, there is an important low-frequency random element to money demand as payment institutions evolve. Because of the instability of demand, a satisfactory price-stabilization policy does not try to prescribe the supply of reserves, but rather uses a feedback mechanism to respond automatically to shifts of the demand function.

Central bankers in all advanced countries have mastered the design of effective feedback mechanisms through a combination of automatic and human components. In the short run, the central bank adjusts reserves as needed to keep a short-term interest rate at a target level. This part is essentially automatic. It accommodates all of the predictable and random shifts in the demand for reserves. In the longer run, human decision making adjusts the interest-rate target to keep inflation at a low level. The central banks of all advanced countries and many lower-income countries have achieved stable prices over the past 15 years through this type of policy making.

\section{B. Controlling the return on the resource}

With the achievement of effective price stability, attention has turned to second-order objectives of policy design with respect to the control of the price level. First is the familiar deadweight burden from the lack of interest on currency and reserves. Second - and less well known-is the churning of the central bank's

\footnotetext{
${ }^{3}$ The study of the demand for currency or reserves is not fundamental to the determination of the price level in alternative monetary regimes, but is central when the resource defining the monetary unit is currency.
} 
portfolio associated with responding to shifts in money demand by adjusting the stock of reserves.

The deadweight burden from the failure to pay interest on reserves is approximately proportional to the squared value of the short-term nominal interest rate. With respect to reserves but not currency, paying interest easily eliminates the deadweight burden. I will not enter the more complicated issue of the technical practicality and economic desirability of paying interest on currency.

The central bank's use of the quantity of reserves as the tool for controlling the price level inevitably results in a huge volume of trades of reserves for interest-bearing debt and vice versa. The accommodation of weekly, seasonal, and weather-related fluctuations in the demand for reserves calls for ceaseless buying and selling of government securities (generally in the form of repurchase agreements).

I have considered this issue earlier in Hall [1983]. Suppose that the central bank maintained a large fixed volume of reserves and responded to shifts in demand for reserves by altering the interest rate paid on those reserves. Specifically, the central bank would pay interest on reserves at a rate that was a specified differential below the rate on, say, the shortest-term treasury bills. The differential would be the daily instrument of monetary policy, replacing openmarket operations. The central bank would use its short-term instrument to peg a short-term interest rate. The operation of monetary policy in the medium term would remain the same as today - the central bank would adjust the target value for the short-term interest rate as needed to keep inflation on target.

Each day, if the short-term interest rate threatened to rise above target, the central bank would expand as needed to push the rate back down to the target level. To expand, the central bank would lower the demand for reserves (instead of raising the supply, as central banks do today). To lower demand, the bank would increase the interest-rate differential between reserves and treasury bills. 
Holders of reserves would attempt to trade lower-yielding reserves for higheryielding short-term securities, and would lower the yield on those securities in the process.

By choosing the normal level of the differential to be small (by creating a large volume of reserves which would be held widely because they paid interest close to the treasury bill rate), the central bank could hold the deadweight burden to a low level. Because the policy eliminates any alteration in the size of the supply of reserves, churning of the central bank's portfolio would be replaced by alterations in the interest rate paid on reserves. It is an open question whether this replacement would result in savings.

In the monetary policy regime I have sketched, based on the use of the reserves differential as the daily instrument, the bigger picture of policy would remain the same. Human beings would determine the interest-rate target and adjust it as needed to stabilize the price level. There is no reason to expect that the performance of monetary policy would be different from that achieved in the recent past using conventional policy.

Could monetary policy be put on autopilot through the adoption of a formula for paying interest on reserves? The answer is yes, and the explanation reveals an interesting connection between paying interest on reserves and the nature of the resource underlying the monetary unit. What follows is drawn from Hall [1997].

Let $p(t)$ be the price level and let $n(t)$ be the short-term nominal interest rate for treasury bills. The autopilot formula for the reserve differential is

$$
d(t)=-[p(t)-1] n(t)+\dot{p}(t)
$$

The target value for the price level is 1 . If the price level rises above 1, the formula says to lower the differential and contract the economy. In addition, the 
formula says to accommodate actual inflation by raising the differential by the amount of current inflation.

To determine the price level under this policy, I proceed as discussed earlier in this chapter. From the formula for the differential, one can see that reserves earn the floating rate $n(t)-d(t)=p(t)$ would hold that the purchasing power of the monetary unit in terms of goods and services, $r_{t}$, is the nominal present discounted value of future interest earnings divided by the current price level:

$$
r(t)=\frac{1}{p(t)} \sum_{t}^{\infty} t_{t}^{t+\tau}(s) d s(t+\tau)
$$

Let

$$
z(t+\tau)=e^{-\frac{t+\tau}{t}(s) d s} p(t+\tau)
$$

Then the nominal value can be written as

$$
\frac{p(t)}{d z}
$$

which is just $p(t)$. So the nominal value of a unit of reserves is equal to the price level. Its real value, $r(t)$, is one.

The final step is to calculate the price level from the relationship,

$$
p_{t}=\frac{1}{x_{t} r_{t}}=\frac{1}{1 \times 1}=1
$$


According to this analysis, the price level resulting from this policy is always 1 .

The analysis rests on only a single behavioral assumption, the present value relation of equation 1 . There are two reasons to doubt that the relation would hold at all closely. First, and of lesser importance, the interest earnings of reserves have different financial risk from treasury bills, so the present value should use a rate with a suitable risk premium or discount. Second, because reserves provide monetary services to their holders-even in an economy close to monetary saturation as proposed here-the valuation should consider these services. The equilibrium price level would actually be less than one so that the differential would be wide enough to accommodate the service value of reserves.

I would not advocate the use of the monetary autopilot. Any feedback rule for monetary policy has to consider seriously the performance in an economy with monetary non-neutrality. A policy that tries to lock the price level to a predetermined target invites serious disturbances to real activity whenever there is an inflationary shock from import prices, wages, or other sources. A realistic rule would have to consider unemployment as well as the price level, as proposed by Taylor [1993], for example. And advocates of such rules generally propose them as guidelines rather than autopilots. 


\section{VI.Controlling the Price Level after the Transition to Cybermoney}

Payment systems are evolving to lessen the public's dependence on currency and on deposits subject to reserve requirements. Will the central bank lose control over the price level as this process continues? ${ }^{4}$

The general framework of this paper suggests that there will remain a wide variety of methods for effective control of the price level even if private, electronic payment methods displace the use of the obligations of the central bank. The most appropriate method, in my view, would be to pay interest on reserves. The differential between the reserve rate and the market rate on treasury bills could decline to make up for the declining demand for reserves derived from the demand for checking accounts. Eventually, when the last checking account and the last dollar bill disappeared from use, reserves would be valued almost entirely from their interest earnings and just a little from the fact that the resource underlying the monetary unit enjoys a service value from that role.

In any case, there is little evidence of disappearance of checking accounts and currency from modern life in any country. Americans in particular cling to the use of checks despite the widespread availability of electronic alternatives that seem to be more convenient. And all central banks, especially the Federal Reserve, enjoy huge markets for their currency because of its anonymity.

\footnotetext{
${ }^{4}$ Jordan and Stevens [1997] discuss this issue. They foresee large reductions in the demand for reserves and currency and are concerned whether central banks can continue to maintain price stability in that setting. Their discussion is entirely limited to current institutions.
} 


\section{The Fiscal Theory of the Price Level}

Sargent and Wallace [1981] began a modern line of thought that examines the relation between the government budget and the price level. This line of thought presumes a modern set of monetary institutions in which the monetary unit and the resource underlying are the same, namely government-issued currency (including reserves). The issuance of currency is a source of revenue to the government. Sims [1994] and Woodford [1994, 1995] are other important contributions in this area. This fiscal theory of the price level presents a view of price determination seemingly quite different from the one described earlier in this chapter. Cochrane [1998] gives a simplified presentation of the fiscal theory.

The fiscal theory of the price level rests on the proposition that, because the government issues nominal instruments, the present value of its excess demands depends on the path of the price level. Equilibrium can only occur when the price level follows a path that results in the government satisfying its intertemporal budget constraint. The equilibrium would be indeterminate but for the government's sensitivity to the price level.

The logic of Sargent and Wallace and the resulting fiscal theory of the price level surely helps explain why Russia and Ukraine cannot have stable price levels today. These countries have government deficits that cannot be funded, apparently, by any method other than the printing of currency.

There are other, simpler ways to make the price level determinate. In the fiscal theory model, the public has to look into the indefinite future to see that the government will eventually go broke unless the price level follows the right path. But consider the following alternative. If the price level is not at the prescribed level, the government pays the purchasers of odd-numbered treasury bills enough at redemption so that their owners earn 5 percent more than they would from even-numbered, normal treasury bills. The market for odd-numbered bills cannot 
clear if the price level departs from the prescribed level. The only possible price level in general equilibrium is the target price level. We do not have to picture the actors in the economy as gazing into the indefinite future to understand the forces that make the price level determinate.

This example shows the connection between the method for controlling the price level advocated earlier in this chapter and the fiscal theory. A policy for paying interest on reserves and linking the interest rate adroitly to the price level seems to be just a variant of standard monetary policy, in which changes in the demand for reserves substitute for changes in the quantity of reserves. But another way to see the same arrangement is that the government creates a fiscal anomaly-paying the wrong interest rate on an important part of the national debt-unless the price level is on target.

\section{Concluding Remarks}

A government has a wide choice of methods for defining the national monetary unit. The unit can be a specified weight of metal or amount of some other physical resource, it can be a security issued by another government, or a security issued by itself. With the definition in place, the government also has a wide choice of methods for controlling the price level. The resource content of the unit can be adjusted systematically over time, as proposed by Irving Fisher and implemented by Chile. The government can adjust the supply of the resource to stabilize its purchasing power, as all advanced economies have done so successfully in the past decade. Or, the government can adjust the demand for the resource and achieve the same control without incurring the costs of churning its portfolio. 
My discussion has only hinted at the tough issues of monetary policy, which are common across all the methods for controlling the price level considered here. It appears that strict price stabilization may result in unstable output and employment. It is probably desirable to permit movements of the price level in the face of some types of macroeconomic shocks and then to reverse these movements gradually afterwards. The reasons lie in the imperfectly understood realm of monetary non-neutrality, which may be defined broadly as sensitivity of real activity to any instrument of monetary policy whose theoretical effect is only to change the price level. As James Tobin has written recently,

The tail wags the dog. By gently touching a tiny tail, Alan Greenspan wags the mammoth dog, the great American economy. Isn't that remarkable? The federal funds rate is the shortest of all interest rates, remote from the rates on assets and debts by which businesses and households finance real investment and consumption expenditures counted in GDP. Why does monetary policy [have real effects]? How? It's a mystery, fully understood by neither central bankers nor economists. ${ }^{5}$

\footnotetext{
5 Tobin [1998, p. 7]. Tobin wrote "Why does monetary policy work?" rather than "Why does monetary policy have real effects?" but I believe my interpretation is consistent with his intent.
} 


\section{References}

Cochrane, John, "A Frictionless View of U.S. Inflation" NBER Working Paper 6646, July 1998 (forthcoming in the NBER Macroeconomics Annual).

Fisher, Irving. "A Compensated Dollar" Quarterly Journal of Economics 27: 213235, February 1913.

Hall, Robert E. "Explorations in the Gold Standard and Related Policies for Stabilizing the Dollar" in Robert E. Hall (ed.) Inflation (Chicago: University of Chicago Press for the NBER) 1982, pp. 111-122.

"Optimal Fiduciary Monetary Systems," Journal of Monetary Economics 12: 33-50, no. 1, July 1983.

"Irving Fisher's Self-Stabilizing Money" American Economic Review Papers and Proceedings 107: 436-438, May 1997

Jordan, Jerry L., and Edward J. Stevens, "Money in the $21^{\text {st }}$ Century" in James A. Dorn (ed.) The Future of Money in the Information Age (Washington, DC: Cato Institute) 1997.

Leeper, Eric. "Equilibrium under 'Active' and 'Passive' Monetary Policies" Journal of Monetary Economics 27:129-147, 1991.

Patinkin, Don. "Irving Fisher and His Compensated Dollar Plan" Federal Reserve Bank of Richmond Economic Quarterly 79: 1-33, Summer 1993.

Sargent, Thomas J., and Neil Wallace, "Some Unpleasant Monetarist Arithmetic" Federal Reserve Bank of Minneapolis Quarterly Review Fall 1981.

Shiller, Robert J., "Indexed Units of Account: Theory and Assessment of Historical Experience" NBER Working Paper 6356, January 1998a.

, "Designing Indexed Units of Account" Cowles Foundation Discussion Paper 1179, May 1998b.

Sims, Christopher, "A Simple Model for the Determination of the Price Level and the Interaction of Monetary and Fiscal Policy" Economic Theory 4:381-399, 1994 University, 1997.

"Fiscal Foundations of Price Stability in Open Economies" Yale 
Taylor, John B. "Discretion versus Policy Rules in Practice", Carnegie-Rochester Conference Series on Public Policy 39:195-214, Autumn 1993.

Tobin, James. "Monetary Policy: Recent Theory and Practice" Cowles Foundation Discussion Paper 1187, July 1998.

Woodford, Michael, "Monetary Policy and Price Level Determinacy in a Cash-inAdvance Economy" Economic Theory 4: 345-389, 1994.

"Price-Level Determinacy without Control of a Monetary Aggregate" Carnegie-Rochester Conference Series on Public Policy 43: 1-46, 1995. 